Western University

Scholarship@Western

Department of Economics Research Reports

Economics Working Papers Archive

1982

\title{
Religion and the Rate of Return on Human Capital: Evidence from Canada
}

Nigel Tomes

Follow this and additional works at: https://ir.lib.uwo.ca/economicsresrpt

Part of the Economics Commons

Citation of this paper:

Tomes, Nigel. "Religion and the Rate of Return on Human Capital: Evidence from Canada." Department of Economics Research Reports, 8222. London, ON: Department of Economics, University of Western Ontario (1982). 
ISSN: $\quad 0318-725 \mathrm{X}$

ISBN： 0-7714-0390-9

RESEARCH REPORT 8222

RELIGION AND THE RATE OF RETURN ON HUMAN CAPITAL: EVIDENCE FROM CANADA

by

Nige1 Tomes

August, 1982

Department of Economics Librany

NOV $\cong 1982$

University of Western Ontario 
RELIGION AND THE RATE OF RETURN ON HUMAN CAPITAL:

EVIDENCE FROM CANADA

\section{Nigel Tomes}

\section{ABSTRACT}

Do rates of return to human capital differ across religious groups? Several recently proposed hypotheses suggest that they do. Returns to schooling, job market experience and a university degree are estimated for various religious groups using the 1971 Canadian Census. The returns to Jews from schooling and experience are substantially higher than to other religious groups. In contrast, however, the 'credential effect' of a degree is zero for Jews and sizeable for other groups. The returns to Protestants from schooling, experience and a degree exceed those to Catholics. These differential payoffs imply sizeable differences in discounted lifetime earnings (human wealth).

forthcoming in the Canadian Journal of Economics (1983). 


\section{INTRODUCTION}

Family background has an important impact on socioeconomic status. The children of richer and more educated parents achieve higher levels of education, occupational attainment and earnings, than their less advantaged contemporaries [Sewal1 and Hauser, 1976; Corcoran et al, 1976]. Yet the influence of family background on economic succiess appears to transcend the measured effects of parental education, occupation and income. Recent analyses of the earnings of brothers and twins [see Griliches' survey, 1979] suggest that other dimensions of the family environment--family values, skills, goals and culture, inherited or acquired during childhood--may be an important channel for the intergenerational transmission of economic status. While eminently plausible, empirical tests of this proposition face an obvious problem. While measures of parents' income and education are often available, reliable measures of family culture, goals and values are much more difficult to obtain. This paper examines religion as one dimension of family culture which influences earnings and the rate of return on human capital. The basic question posed is an empirical one: "Does the return to schooling and job market experience vary across religious groups?" Data from the 1971 Canadian Census on the earnings of white native-born Canadian males is used to quantify the magnitude of religious differences in the monetary rewards to schooling and job-market experience. Empirical evidence is presented of sizeable differentials in rates of return to schooling, experience and possession of a university degree, which translate into substantial differences between religious groups in discounted 1ifetime earnings (human wealth)。 
The remainder of this paper proceeds as follows. Section II summarizes recent theoretical models of the family which suggest that dimensions of family culture, such as religion, may play an important role in determining parental investments in children. The empirical research of economists and sociologists pertaining to this question is also briefly summarized. Section III presents our empirical analysis of the earnings of Canadian males. Section IV contains a brief summary and conclusions.

II. RELIGION AND THE RATE OF RETURN ON HUMAN CAPITAL

(a) Theoretical Perspectives

In contrast to earlier theoretical models which consider isolated individuals, recent discussions of human capital accumulation explicitly recognize the role of the family. In the model of income determination recently proposed by Becker and Tomes (1979), "children are assumed to receive endowments... that are determined by the reputation and 'connections' of their families;...the genetic constitutions of parents...; and the learning, skills and goals acquired through belonging to a particular family culture", p. 1156. Such endowments are expected to be important determinants of income, human capital investments and the rate of return on such investments. 1

The obvious difficulty with testing these predictions is to find operational measures of child endowments. The working hypothesis of this paper is that religious affiliation represents a measurable dimension of endownents. Individuals belonging to the same religion are assumed to possess endowments which are more similar than individuals in different religions.

Recent discussion concerning differences in the economic achievement of Jews and Non-Jews adopts this view. Becker (1981) states that "[0]ver the last 150 years Jews have invested more in human capita1... and in recent decades have had higher incomes.... I believe that the high achievement of Jewish families are explained by high marginal rates of return to investments in the 
education, health and other human capital of their children", p. 110. Thus Becker suggests that, because they have greater endowments of ability and other traits, Jews receive higher returns on human capital investments and therefore make greater investments in this form of capital, than other groups. In contrast, Brenner and Kiefer (1981) have recently argued that because of their past cultural history of the expropriation of non-human wealth, Jews make greater investments in human capital, ${ }^{2}$ which is embodied and transportable, than other groups and receive a lower marginal rate of return. Both these hypotheses imply that Jews make greater human capital investments and receive higher earnings than other religious groups. However, Becker's hypothesis implies a higher rate of return, while Brenner and Kiefer predict a lower rate of return on human capital investments.

Moreover, the investments and returns of other religious groups are also expected to differ. Economic demographers have frequently assumed that Roman Catholic families face a price of child numbers which differs from that of other families (e.g., Carliner et al, 1980; Robinson and Tomes, 1982). When this assumption is incorporated into quality-quantity models of choice [Becker and Lewis, 1974; Becker and Tomes, 1976; Edlefsen, 1981] it implies that the human capital investment and rate of return of Catholics will differ from that of other religious groups. In particular, with equal family resources, Catholics are predicted to invest less per child and receive a higher marginal rate of return than other religious groups.

In summary, although recent hypotheses yield differing predictions regarding religious differences in investments and rates of return, they do suggest that such differences exist. Whether the data confirm some hypotheses and reject others remains to be seen. Before presenting empirical results we briefly review previous research. 


\section{(b) Previous Empirical Research}

The author has been unable to locate any representative Canadian data sets which include information on the religious affiliation of both parents and children. ${ }^{3}$ The few available U.S. studies suggest that the intergenerational transmission of religious affiliation within the family is very high. Warren (1970) reports that $90 \%$ of men retain their background religion up to the time of marriage. Similarly, Janssen and Hauser (1981) found in an 18 year follow-up that only $12.6 \%$ of individuals from Catholic families currently reported themselves as non-Catholics and $10.9 \%$ of individuals from non-Catholic families reported their current religion as Catholic [Table 2, p. 515]. These figures imply a high degree of intergenerational continuity in religion and suggest that it may be appropriate to view current religious affiliation as a good proxy for the religion of the family of orientation. On this basis, religion has typically been treated as a predetermined dimension of family background by researchers.

A longer version of this paper (Tomes, 1982) summarizes a number of U.S. studies of income differentials between religious groups. The finding that Jews receive higher incomes than non-Jews, after controling for a variety of characteristics appears to be universal. The ranking of Catholics and Protestants is more controversia1; Gockel (1969), Taubman (1975) and Greeley (1976) conclude that Catholics earn more than similar Protestants, while Featherman (1971) and Roof (1981) find no significant difference.

It is important to note that the standard equation estimated by these investigators assumes that the effect of religion on income (or earnings) is additive and does not allow for interaction terms, which would permit the rate of return on education to differ across religious groups. ${ }^{4}$ 
The recent study by Chiswick (1982) which examines the earnings of Jewish and non-Jewish adult U.S. men ${ }^{5}$ using the 1970 U.S. Census is more general in this regard. Chiswick adopts the human capital formulation, regressing the 1 og of earnings on schooling, experience, etc. Controlling for location, marital status and country of origin (for non-Jews), the rate of return to schooling of Jews exceeds that of non-Jews by $19 \%(0.081$ versus 0.068$)$. Thus Chiswick presents strong evidence that the return to human capital received by Jews exceeds that of other groups. A major drawback of Chiswick's work is that he is unable to directly identify Jews, either by religious affiliation or Jewish ethnic background. Jews are identified in his sample as individuals with a mother tongue that is either Yiddish, Hebrew or Ladino. However, this procedure is likely to select only a subset of Jews who may differ in a systematic fashion from all Jews. For this reason Chiswick's results should be treated with caution. Secondly Chiswick's research is focused exclusively on Jewish-non Jewish differentials and does not examine religious differences with in the non-Jewish population. There has been little systematic research on earnings or income differentials by religion in Canada. Using 1971 Canadian Census data Richmond and Kalback (1980) perform a regression analysis on the total income of the employed adult (15+) population [p. 366]. They find that "the substantially higher levels of income of the Jewish population were almost entirely explained by higher levels of urbanization and education. There is a very small direct effect of being Jewish" [p. 367]. The "very small direct effect" indicates that Jews earn $\$ 2,011$ (or 22.7\%!) more than other individuals with the same characteristics. ${ }^{6}$ The effect of Catholic religious affiliation is small and insignificant. Richmond and Kalback do not investigate interactions between religion and human capital variables. 
Kuch and Haessel (1979) estimate earnings functions for Canadian ethnic groups based on a sample of employed males age 14+ from the 1971 Census. Their estimate of the rate of return to schooling for Jews $(6.61 \%)$, is not significantly different from the British reference group (7.47\%) or the average for the whole sample (6.28\%). However, the rate of return to experience for Jews was found to be significantly higher than the reference group [pp. 74, 173]. ${ }^{7}$ The results of both these studies, however, may be subject to sample selection bias since members of the younger (college age) and older (retirement age) cohorts satisfying the criterion of positive earnings are likely to be a non-random sample of the population. For this reason we re-examine whether the earnings functions of religious groups differ.

\section{EMPIRICAL RESULTS}

The empirical results are based on an analys is of the $1 / 100$ sample of the 1971 Canadian Census. An important advantage of these data is that, in contrast to data generated by the U.S. government, the Canadian Census contains direct measures of religious affiliation. Thus, in contrast to Chiswick's U.S. study, we do not have to identify Jews via mother tongue. A1so we can identify Roman Catholics and major Protestant denominations. The Canadian Census does not contain an extensive list of family background variables, only information on respondents' religious affiliation, ethnic origin, mother tongue and whether or not parents were foreign-born is available. The estimated effects of religion are therefore'gross effects', not controlling for parents' income, education and other dimensions of socio-economic status in the family of origin.

The sample is restricted to native-born white males, age 25-64 with positive earnings. ${ }^{8}$ The variables employed in the empirical analysis are defined in Table 1. The means of selected variables for various subsamples are presented in Table $A$ of the Appendix. 
TABLE 1: DEFINITIONS OF VARIABLES

LNEARN:

,

EDUC:

T:

TSQR :

DEGREE* :

GOVI* :

SELF':

LANGUAGE* :
Natural $\log$ of earnings (Income from vages and salaries plus Net Income from self-employment) 1970

Years of schooling (See Appendix for details of coding.)

Experience $=($ Age - EDUC -6$)$

Experience squared

University Degrce

Employed in the public sector [Industry = "public administration and defense"]

Self-employed in incorporated or unincorporated business

Ability to converse in English and French

ENG: English only (reference group)

FR: $\quad$ French only

BILFR: Bilingual French (language most frequently spoken in home is French, fluent in both English and French)

BILENG :

Bilingual English (language most frequently spoken in home is English, fluent in both English and French)

MOTTER TONGUE*

FORMTG :

Mother Tongue neither Fnglish nor French

Natural $\log$ of weeks worked 1970

LNWEFKS :

URBAN/RURAL LOCATION*:

(1971) place of residence

URBAN:

Urban arca population $\geq 30,000$ (reference group)

TOWN:

Urban area population $<30,000$

RNF :

Rural Non-Farm

FARM:

Farm

PROVINCE/REGION OF LOCATION $1971^{*}$

NFL: Newfoundland, MARIT: Maritime Provinces: (Nova Scotia, New Brunswick)

PQ: Qucbec, ONr: Ontario (reference group), PR: Prairic Provinces (Saskatchewan, Manjtoba, Alberta), BC: British Columbia

NOTMAR* :

RELIGION*

RJEW: Jewish

RCATH: $\quad$ Roman Catholic

RPROT: Protestant (Ang1ican, Baptist, Lutheran, Pentecostal, Presbytcrian or United Church)

OTHER/NO REI:

ETHINIC BACKGROUND ${ }^{*}$

BRITISH ISLES :

ETHFR:

Not married (married = married spouse present or absent); i.c., single, widowed, divorced or separated

other (Greek Orthodox, Mennonite/Huttcrite, Ukranian Catholic, etc.) or 'No Religion'

Ethnic or cultural background traced through father's side

Reference Group (English, Irish, Welsh, Jther British Isles)

French

West Contral Europe (Austrian, Gernan or Netherlands)

East Central Europe (Czech, Hungarian, Polish or Slovak)

Southern Europe (Italian)

Russian or Ikranian

RUSSIA :

Scandinavian or Finnish

SCAN :

OTHER :

Other or Unknown

BIRTIIPIACE OF PARENTS*

FBF : $\quad$ Father born outside Canada

FBM: Mother born outside Canada 
We adopt the human capital estimating equation (Mincer, 1974) with the log of earnings as the dependent variable and schooling, experience and its square as major explanatory variables. Following Mincer and others we control for weeks worked. ${ }^{9}$ These variables are augmented with measures of fluency in the official languages. Language skills represent a dimension of human capital which is likely to have differential payoffs in Quebec and the rest of Canada (excluding Quebec) [Carliner, 1981]. For this reason, we partition the sample between Quebec and the rest of Canada.

Because the cost of living is known to vary across provinces and between urban and rural areas we introduce a series of dummy variables to control for province/region and urban/rural location. In addition, since it is often observed that married males earn more than other males, possibly because of their greater commitment to the labour market or higher ability, we introduce a dummy variable for marital status.

Three additional control variables appear in our estimating equation, which do not appear in most earnings functions. First, we introduce a dummy variable indicating the possession of a degree. Since models of human capital emphasize the use of time in school to accumulate skills, it is difficult to rationalize a discrete increase in earnings associated with obtaining a degree as the outcome of such an accumulation process [01sen, white and Shefrin, 1979]. It seems more plausible to view this 'credential effect' as being a proxy for ability. ${ }^{10}$ Holding the DEGREE variable constant, we interpret the coefficient on schooling as the 'rate of return' on the types of skills emphasized in the human capital literature. Second, we control for self-employment status (SELF). The reported earnings of the self-employed may differ from that of employed 
workers due to differences in the treatment of wage and capital income, differences in risk and autonomy associated with alternative employment statuses, and a variety of other reasons. Finally, since the reward structures in the government and private sectors differ [Gunderson, 1979], we control, in a simple manner, for employment in the public sector by introducing the GOVT variable. 11 Our major interest centers on differences between religious groups. We identify Jews according to their religious affiliation. ${ }^{12}$ Amongst non-Jews we distinguish between Roman Catholics, members of the major Protestant denominations (Anglican, Baptist, Lutheran, Pentecostal, Presbyterian, and United Church) and a residual group (OTHER/NO REL) composed of other religious affiliations (Greek Orthodox, Mennonite/Hutterite, Ukranian Catholic, etc.) and 'No Religion'. For non-Jews we include a set of ethnic dummy variables indicating the country of origin traced through the father's side. ${ }^{13}$ In addition we enter dummy variables indicating whether the individual's father and mother were foreign-born, and if his mother tongue was neither official language. Thus we hold constant some dimensions of family background, while estimating the impact of religion on earnings and the rate of return to human capital. Table A (Appendix) reports the sample means for various subsamples. These figures indicate a sizeable earnings advantage for Jews of almost $80 \%$ ( $\$ 14,000$ versus $\$ 7,800$ for the whole sample). However, Jews have 2.6 extra years of schooling, are more likely to possess a degree and to live in urban areas, especially Toronto or Montreal. Hence, the higher earnings of Jews may simply reflect the fact that each of these characteristics are usually associated with higher earnings. However, Jews are also less likely to be employed by the government and are more likely to be self-employed, which may 
tend to lower their earnings. Comparing the other groups, Protestants earn about $6 \%$ more than the sample mean $(\$ 8,300)$, and Catholics $7 \%$ less $(\$ 7,250)$. These differentials may reflect in part the fact that Catholics are more likely to speak French (FR or BILFR) and tend to reside in Quebec, while the converse is true of Protestants. Moreover Protestants have one more year of schooling. In order to analyze the sources of these earnings differentials we turn to a regression analysis.

\section{Empirical Results}

Table 2 reports earnings regression for the four religious groups, estimated over the entire sample. As anticipated the "human capital" variables-schooling, experience and its square--are important determinants of 1 og earnings. The coefficient estimates display substantial variation across religious groups. In terms of the returns to schooling Jews rank the highest, followed by Protestants, Catholics, and lastly, the residual group (OTHER/NO REL). Several of these differences are statistically significant; ${ }^{14}$ the return to Jews is significantly greater than to the residual group at the $10 \% 1$ evel $(t=1.702)$, the difference between the returns to protestants and those to both Catholics and the residual group is statistically significant at better than the $5 \%$ leve1 $(t=2.55$ and 3.15, respectively). Judged in relative terms the differences in returns to schooling are substantial. The (weighted) average return to schooling is $3.89 \%$. The returns to schooling received by Jews $(5.77 \%)$, exceed this figure by $48 \%,{ }^{15}$ Protestants by $9 \%$. On the other hand, Catholics and the residual group (OTHER/NO REL) receive returns that are $5 \%$ and $17 \%$ less than the mean, respectively. 
TABLE 2: EARNINGS FUNCTIONS FOR RELIGIOUS GROUPS IN CANADA

\begin{tabular}{|c|c|c|c|c|}
\hline Col \# & (1) & (2) & (3) & (4) \\
\hline Group & RJEW & RPROT & RCATH & OTHER/NO REL \\
\hline EDUC & $\begin{array}{r}0.0577 \\
{[2.857]}\end{array}$ & $\begin{array}{r}0.0424 \\
{[17.855]}\end{array}$ & $\begin{array}{r}0.0369 \\
{[17.362]}\end{array}$ & $\begin{array}{r}0.0323 \\
{[6.261]}\end{array}$ \\
\hline $\mathbf{T}$ & $\begin{array}{r}0.0518 \\
{[3.710]}\end{array}$ & $\begin{array}{r}0.0364 \\
{[17.583]}\end{array}$ & $\begin{array}{r}0.0292 \\
{[16.084]}\end{array}$ & $\begin{array}{r}0.0377 \\
{[9.374]}\end{array}$ \\
\hline TSQR & $\begin{array}{c}-.00104 \\
{[3.969]}\end{array}$ & $\begin{array}{c}-.000648 \\
{[17.631]}\end{array}$ & {$\left[\begin{array}{c}-.000508 \\
{[16.092]}\end{array}\right.$} & $\begin{array}{l}-.000691 \\
{[9.628]}\end{array}$ \\
\hline $\begin{array}{l}\text { LNWEEKS } \\
\text { DEGREE }\end{array}$ & $\begin{array}{c}1.146 \\
{[8.993]} \\
0.074 \\
{[0.506]}\end{array}$ & $\begin{array}{c}0.918 \\
{[57.926]} \\
0.337 \\
{[13.757]}\end{array}$ & $\begin{array}{c}0.761 \\
{[63.361]} \\
0.225 \\
{[9.219]}\end{array}$ & $\begin{array}{c}0.887 \\
{[31.435]} \\
0.288 \\
{[5.995]}\end{array}$ \\
\hline FR & $\begin{array}{l}-1.198 \\
{[1.058]}\end{array}$ & $\begin{array}{l}-0.169 \\
{[2.126]}\end{array}$ & $\begin{array}{l}-0.145 \\
{[5.432]}\end{array}$ & $\begin{array}{l}-0.252 \\
{[2.108]}\end{array}$ \\
\hline BILFR & $\begin{array}{c}0.063 \\
{[0.110]}\end{array}$ & $\begin{array}{l}-0.055 \\
{[0.547]}\end{array}$ & $\begin{array}{l}-0.054 \\
{[2.249]}\end{array}$ & $\begin{array}{l}-0.086 \\
{[0.851]}\end{array}$ \\
\hline BILENG & $\begin{array}{c}0.066 \\
{[0.574]}\end{array}$ & $\begin{array}{c}0.003 \\
{[0.120]}\end{array}$ & $\begin{array}{c}0.013 \\
{[0.555]}\end{array}$ & $\begin{array}{l}-0.060 \\
{[1.185]}\end{array}$ \\
\hline FORMTG & $\begin{array}{l}-0.250 \\
{[1.784]}\end{array}$ & $\begin{array}{l}-0.073 \\
{[2.432]}\end{array}$ & $\begin{array}{l}-0.083 \\
{[2.600]}\end{array}$ & $\begin{array}{c}0.028 \\
{[0.768]}\end{array}$ \\
\hline NOTMAR & $\begin{array}{l}-0.384 \\
{[3.522]}\end{array}$ & $\begin{array}{c}-0.283 \\
{[18.588]}\end{array}$ & $\begin{array}{c}-0.288 \\
{[22.462]}\end{array}$ & $\begin{array}{l}-0.247 \\
{[8.719]}\end{array}$ \\
\hline SELF & $\begin{array}{c}0.245 \\
{[2.806]}\end{array}$ & $\begin{array}{c}-0.171 \\
{[10.153]}\end{array}$ & $\begin{array}{l}-0.082 \\
{[5.281]}\end{array}$ & $\begin{array}{l}-0.225 \\
{[6.629]}\end{array}$ \\
\hline GOVT & $\begin{array}{l}-0.080 \\
{[0.316]}\end{array}$ & $\begin{array}{c}0.046 \\
{[2.550]}\end{array}$ & $\begin{array}{c}0.037 \\
{[2.201]}\end{array}$ & $\begin{array}{c}0.079 \\
{[1.861]}\end{array}$ \\
\hline TOWN & $\begin{array}{c}0.361 \\
{[1.182]}\end{array}$ & $\begin{array}{l}-0.105 \\
{[7.500]}\end{array}$ & $\begin{array}{l}-0.022 \\
{[1.795]}\end{array}$ & $\begin{array}{l}-0.057 \\
{[1.817]}\end{array}$ \\
\hline $\mathrm{RNF}$ & $\begin{array}{l}-0.552 \\
{[0.684]}\end{array}$ & $\begin{array}{c}-0.195 \\
{[12.739]}\end{array}$ & $\begin{array}{c}-0.148 \\
{[10.324]}\end{array}$ & $\begin{array}{l}-0.207 \\
{[6.217]}\end{array}$ \\
\hline FARM & $*$ & $\begin{array}{c}-0.554 \\
{[24.633]}\end{array}$ & $\begin{array}{c}-0.454 \\
{[19.340]}\end{array}$ & $\begin{array}{c}-0.594 \\
{[12.961]}\end{array}$ \\
\hline NFL & $*$ & $\begin{array}{l}-0.189 \\
{[6.246]}\end{array}$ & $\begin{array}{l}-0.278 \\
{[7.218]}\end{array}$ & $\begin{array}{l}-0.460 \\
{[4.815]}\end{array}$ \\
\hline MARIT & $\begin{array}{l}-0.789 \\
{[2.487]}\end{array}$ & $\begin{array}{l}-0.188 \\
{[9.711]}\end{array}$ & $\begin{array}{l}-0.204 \\
{[9.065]}\end{array}$ & $\begin{array}{l}-0.129 \\
{[1.876]}\end{array}$ \\
\hline
\end{tabular}


TABLE 2 (Cont'd.)

\begin{tabular}{|c|c|c|c|c|}
\hline $\operatorname{Col} \#$ & (1) & (2) & (3) & (4) \\
\hline Group & RJEW & RPROT & RCATH & OTHER/NO RE \\
\hline $\mathrm{PQ}$ & $\begin{array}{l}-0.026 \\
{[0.227]}\end{array}$ & $\begin{array}{l}: 0.041 \\
{[1.432]}\end{array}$ & $\begin{array}{l}-0.023 \\
{[1.302]}\end{array}$ & $\begin{array}{l}-0.004 \\
{[0.057]}\end{array}$ \\
\hline PR & $\begin{array}{l}-0.109 \\
{[0.794]}\end{array}$ & $\begin{array}{l}-0.120 \\
{[8.180]}\end{array}$ & $\begin{array}{l}-0.138 \\
{[6.226]}\end{array}$ & $\begin{array}{l}-0.181 \\
{[5.878]}\end{array}$ \\
\hline $\mathrm{BC}$ & $\begin{array}{l}-0.123 \\
{[0.536]}\end{array}$ & $\begin{array}{c}0.070 \\
{[4.107]}\end{array}$ & $\begin{array}{l}-0.010 \\
{[0.338]}\end{array}$ & $\begin{array}{c}0.056 \\
{[1.787]}\end{array}$ \\
\hline FBF & $\begin{array}{c}0.075 \\
{[0.545]}\end{array}$ & $\begin{array}{l}-0.003 \\
{[0.185]}\end{array}$ & $\begin{array}{l}-0.018 \\
{[0.834]}\end{array}$ & $\begin{array}{c}0.003 \\
{[0.089]}\end{array}$ \\
\hline F BM & $\begin{array}{l}-0.027 \\
{[0.208]}\end{array}$ & $\begin{array}{c}0.012 \\
{[0.792]}\end{array}$ & $\begin{array}{c}0.043 \\
{[1.946]}\end{array}$ & $\begin{array}{l}-0.024 \\
{[0.777]}\end{array}$ \\
\hline ETHFR & $*$ & $\begin{array}{l}-0.010 \\
{[0.276]}\end{array}$ & $\begin{array}{c}0.014 \\
{[0.708]}\end{array}$ & $\begin{array}{l}-0.027 \\
{[0.453]}\end{array}$ \\
\hline WCEUR & $\star$ & $\begin{array}{l}-0.001 \\
{[0.072]}\end{array}$ & $\begin{array}{c}0.017 \\
{[0.564]}\end{array}$ & $\begin{array}{c}0.016 \\
{[0.421]}\end{array}$ \\
\hline ECEUR & $*$ & $\begin{array}{c}0.091 \\
{[1.723]}\end{array}$ & $\begin{array}{c}0.050 \\
{[1.316]}\end{array}$ & $\begin{array}{c}0.055 \\
{[0.675]}\end{array}$ \\
\hline SEUR & * & $\begin{array}{c}0.112 \\
{[1.078]}\end{array}$ & $\begin{array}{c}0.012 \\
{[0.316]}\end{array}$ & $\begin{array}{c}0.111 \\
{[0.791]}\end{array}$ \\
\hline SCAN & * & $\begin{array}{c}0.004 \\
{[0.142]}\end{array}$ & $\begin{array}{c}0.202 \\
{[2.370]}\end{array}$ & $\begin{array}{c}0.143 \\
{[2.216]}\end{array}$ \\
\hline RUSSIA & $*$ & $\begin{array}{c}0.030 \\
{[0.767]}\end{array}$ & $\begin{array}{c}0.070 \\
{[1.346]}\end{array}$ & $\begin{array}{c}0.023 \\
{[0.564]}\end{array}$ \\
\hline OTHER & $*$ & $\begin{array}{c}0.027 \\
{[0.553]}\end{array}$ & $\begin{array}{c}0.024 \\
{[0.475]}\end{array}$ & $\begin{array}{l}-0.005 \\
{[0.086]}\end{array}$ \\
\hline CONSTANT & $\begin{array}{l}-0.012 \\
{[1.757]}\end{array}$ & $\begin{array}{c}0.027 \\
{[0.392]}\end{array}$ & $\begin{array}{c}0.734 \\
{[12.728]}\end{array}$ & $\begin{array}{c}0.231 \\
{[1.758]}\end{array}$ \\
\hline $\mathrm{R}^{2}$ & 0.388 & 0.396 & 0.375 & 0.395 \\
\hline $\mathbf{N}$ & 374 & 14,390 & 15,270 & 3,692 \\
\hline
\end{tabular}

NOTES: 1. The dependent variable is the natural $10 \mathrm{~g}$ of earnings LNEARN.

2. Absolute value of $t$-statistics reported in parentheses beneath each coefficient. 
For the three major religious groups the initial returns to job market experience (evaluated at $\mathrm{T}=0$ ) display a similar pattern: the returns to Jews exceeds that to both Protestants and Catholics. These differences are significant at the $10 \%$ and $5 \%$ levels $(t=1.75$, and 2.48$)$, respectively. The experience coefficient of Protestants is significantly greater than that for Catholics $(t=2.41)$. In contrast to the schooling coefficient, the returns to experience for the residual group does not differ significantly from any of the other three groups.

It is interesting also to compare across religious groups the earnings advantage associated with university graduation. Holding years of schooling constant, the 'credential' effect of a degree augments the earnings of Protestants by $40 \%$, Catholics by $25 \%$, Jews by $8 \%$ and the residual group by $33 \%$. The return to a university degree for Protestants is significantly greater than to either Catholics or Jews $(t=2.97$ and 2.10 , respectively). Thus comparing Protestants and Catholics, who together constitute $88 \%$ of our sample, the returns to schooling, experience and a degree are substantially and significantly higher for Protestants.

If we compare Jews with the other religious groups a different picture emerges. Although the returns to Jews from schooling and experience exceed those of other groups, the converse is true of the payoff to a degree. In fact the degree coefficient for Jews is small and insignificant. We cannot reject the hypothesis that there is no credential effect for Jews. Although the degree coefficient for this group is imprecisely estimated, the payoff to Jews from a university degree is significantly different from the payoff to Protestants, the group receiving the largest payoff. For Jews university graduation does not appear to increase earnings beyond its effect on cumulative 
years of schooling. Stated differently, the returns to Jews from an extra year of university without a degree are the same as for a year with a degree. For non-Jews, however, the returns to an additional year of university without a degree are substantially lower than with a degree. ${ }^{16}$

The constant terms also differ across equations. ${ }^{17}$ Comparing the three major religious groups we observe that the group with the highest returns to schooling and experience (Jews) is characterized by the smallest intercept, while the converse is true for Catholics who have the lowest returns to human capital.

These results imply that the differences in earnings and lifetime human wealth between religious groups are not constant, but vary with the levels of schooling and experience. Comparing Jews with non-Jews, the advantage to Jews increases with schooling up to university without a degree. Beyond this point, the fact that the payoffs to a degree are lower for Jews attenuates the Jewish/Non-Jewish earnings differential among university graduates. Comparing Protestants and Catholics the differential in earnings and lifetime human wealth is smallest among individuals with no high school. The earnings advantage of Protestants increases with schooling, being greatest among university graduates, reflecting the higher returns to Protestants from possessing a degree. Other important differences emerge in Table 2. The coefficients on LNWEEKS differ significantly. For Jews the elasticity of earnings with respect to weeks worked exceeds unity, whereas for the other groups this elasticity is less than one, being lowest for Catholics. One possible explanation is that the supply schedule of weeks worked differs, being upward sloping for Jews and backward bending for the other groups. Alternatively, the different 
coefficients may reflect variations in the seasonality of employment. Other points of contrast between Jews and non-Jews deserve note. Among Jews, the self-employed earn a premium compared to the employed, whereas for non-Jews the comverse is true. Among non-Jews employment in the public sector earns a premium of $3.8-8.2 \%$, a range that encompasses the estimates of Gunders on (1979). For Jews, there is no evidence of "rents" from public sector employment. However, given the imprecise estimate of the GOVT coefficient for Jews this difference is not statistically significant.

The remaining results in Table 2 require little discussion. Language skills are important determinants of earnings in Canada ${ }^{18}$ [Vaillancourt, 1980; Carliner, 1981]. Our results imply that monolingual francophones earn 15.6-28.7\% less than anglophones [Cols (2)-(4)]. Bilingual francophones earn 5.6-8.9\% less than the referance group, but this difference is only significant among Catholics. These results suggest a positive return to second-language acquisition for this group. On the other hand, these regressions present no evidence of significant returns to bilingualism for the English. The significance of the foreign mother tongue variable (FORMTG) suggests that Canadians whose mother tongue is neither official language are less fluent in the dominant languages of Canada and therefore earn less. Within all religious groups individuals who are not currently married earn substantially less than similar married males. The urban/rural and provincial/regional dummy variables are frequently significant, presumably reflecting, amongst other things, cost of living differentials. Lastly variables indicating foreign-born parents and ethnic origin are rarely significant. 
Table 3 presents the summary results of estimating earnings functions for the four religious groups over various subsamples. The estimated equations have the same specification as those in Table 2. The top portion of the table divides the sample between Quebec and the rest of Canada, since the returns to language skills and possibly also other forms of human capital may differ. The lower portion of the Table presents results from the independent sample covering the Toronto and Montreal metropolitan areas. These latter samples permit a better control for urban location, since it is known that within areas of $30,000+$ population Jews are concentrated in the larger metropolitan areas. ${ }^{19}$ It is possible therefore that the Jewish/non-Jewish differentials reported in Table 2 reflect differences in spatial location. The important results in Table 3 can be briefly summarized. For Canadajg Quebec and Toronto the results are similar to those reported in Table 2 . The returns to schooling and job experience for Jews exceed those of other groups. The differentials are larger than in Table 2 and are statistically significant. The degree coefficient for Jews is smaller than for other groups, but the differences are not statistically significant. The return to schooling for Protestants exceeds that of both Catholics and the residual group. Also in Canada excluding Quebec the experience and degree coefficients for Protestants are significantly larger than those for Catholics. The differences between Catholics and the residual group are not statistically significant. These results reinforce the earlier conclusions that the returns to human capital (schooling and experience) for Jews exceed those of other groups. However, the 'credential' effect of a degree is no larger for Jews. Moreover, the returns to schooling, experience and a university degree for Protestants exceed those to Catholics. 
TABLE 3: EARNINGS FUNCTIONS FOR RELIGIOUS GROUPS: SUBSAMPLES

- Row \# Religious Group

$\begin{array}{llllll}\text { EDUC } & \mathrm{T} & \mathrm{TSQR} & \mathrm{R} & \mathrm{N}\end{array}$

A. Canada excl. Quebec

$\begin{array}{llrrccrrr}\text { 1. } & \text { RJEW } & 0.0827 & 0.0686 & -.00130 & 0.176 & 0.526 & 221 \\ & & {[3.339]} & {[4.339]} & {[4.195]} & {[1.071]} & & \\ \text { 2. } & \text { RPROT } & 0.0416 & 0.0361 & -.000648 & 0.341 & 0.390 & 13,644 \\ & & {[16.833]} & {[16.822]} & {[16.998]} & {[13.263]} & & \\ \text { 3. } & \text { RCATH } & 0.0373 & 0.0274 & -.000503 & 0.186 & 0.374 & 5,910 \\ & & {[10.727]} & {[8.964]} & {[9.343]} & {[4.541]} & & \\ \text { 4. NO REL/OTHER } & 0.0325 & 0.0374 & -.000682 & 0.291 & 0.389 & 3,462 \\ & & {[6.030]} & {[8.964]} & {[9.206]} & {[5.788]} & & \end{array}$

B. Quebec

\begin{tabular}{|c|c|c|c|c|c|c|c|}
\hline 5. & RJEW & $\begin{array}{r}0.0449 \\
{[1.264]}\end{array}$ & $\begin{array}{r}0.0266 \\
{[0.931]}\end{array}$ & $\begin{array}{r}-.000647 \\
{[1.296]}\end{array}$ & $\begin{array}{l}-0.239 \\
{[0.813]}\end{array}$ & 0.252 & 153 \\
\hline 6. & RPROT & $\begin{array}{r}0.0561 \\
{[6.811]}\end{array}$ & $\begin{array}{r}0.0397 \\
{[5.361]}\end{array}$ & $\begin{array}{r}-.000622 \\
{[4.759]}\end{array}$ & $\begin{array}{c}0.278 \\
{[3.507]}\end{array}$ & 0.520 & 746 \\
\hline 7. & RCATH & $\begin{array}{r}0.0369 \\
{[13.734]}\end{array}$ & $\begin{array}{r}0.0307 \\
{[13.643]}\end{array}$ & $\begin{array}{c}-000519 \\
{[13.351]}\end{array}$ & $\begin{array}{c}0.248 \\
{[8.147]}\end{array}$ & 0.378 & 9,360 \\
\hline 8. & NO REL/OTHER & $\begin{array}{r}0.0274 \\
{[1.440]}\end{array}$ & $\begin{array}{r}0.0425 \\
{[2.684]}\end{array}$ & $\begin{array}{r}-000857 \\
{[2.539]}\end{array}$ & $\begin{array}{c}0.221 \\
{[1.274]}\end{array}$ & 0.522 & 230 \\
\hline
\end{tabular}

- C. Toronto CMA

$\begin{array}{llrrrrrr}\text { 9. } & \text { RJEW } & 0.0908 & 0.0842 & -.00146 & 0.091 & 0.436 & 153 \\ & & {[3.331]} & {[4.262]} & {[3.900]} & {[0.443]} & & \\ \text { 10. } & \text { RPROT } & 0.0577 & 0.0347 & -.000568 & 0.203 & 0.321 & 1 ; 931 \\ & & {[10.708]} & {[7.610]} & {[6.814]} & {[4.181]} & & \\ \text { 11. } & \text { RCATH } & 0.0324 & 0.0234 & -.000423 & 0.304 & 0.368 & 653 \\ & & {[3.687]} & {[2.846]} & {[2.792]} & {[3.141]} & & \\ \text { 12. NO REL/OTHER } & 0.0480 & 0.0373 & -.000728 & 0.148 & 0.315 & 430 \\ & & {[4.025]} & {[3.917]} & {[4.010]} & {[1.506]} & & \end{array}$

D. Montreal CMA

\begin{tabular}{|c|c|c|c|c|c|c|c|}
\hline 13. & RJEW & $\begin{array}{r}0.0201 \\
{[0.509]}\end{array}$ & $\begin{array}{r}0.0443 \\
{[1.665]}\end{array}$ & $\begin{array}{r}-.000840 \\
{[1.775]}\end{array}$ & $\begin{array}{c}0.400 \\
{[1.367]}\end{array}$ & 0.308 & 139 \\
\hline 14. & RPROT & $\begin{array}{r}0.0260 \\
{[2.220]}\end{array}$ & $\begin{array}{r}0.0402 \\
{[4.074]}\end{array}$ & $\begin{array}{r}-.000662 \\
{[3.691]}\end{array}$ & $\begin{array}{c}0.479 \\
{[4.387]}\end{array}$ & 0.392 & 520 \\
\hline 15. & RCATH & $\begin{array}{r}0.0362 \\
{[9.365]}\end{array}$ & $\begin{array}{r}0.0340 \\
{[10.366]}\end{array}$ & $\begin{array}{c}-.000592 \\
{[10.415]}\end{array}$ & $\begin{array}{c}0.325 \\
{[7.697]}\end{array}$ & 0.377 & 3,801 \\
\hline 16. & NO REL/OTHER & $\begin{array}{r}0.0146 \\
{[0.689]}\end{array}$ & $\begin{array}{r}0.0419 \\
{[2.399]}\end{array}$ & $\begin{array}{r}-.000763 \\
{[2.296]}\end{array}$ & $\begin{array}{c}0.402 \\
{[2.190]}\end{array}$ & 0.418 & 163 \\
\hline
\end{tabular}

NOTES: 1. The dependent variable is the natural $10 \mathrm{~g}$ of earnings LNEARN.

2. Absolute value of t-statistics reported in parentheses beneath each coefficient.

3. In addition to the variables listed above all regressions contained a constant term, four language dummies, NOTMAR, SELF, GOVT, FBF, FBM and the appropriate set of urban/rural and provincial/regional dummy variables. Regressions for non-Jews contained the set of seven ethnic dummy variables. 
The results for Quebec and Montreal display less marked differentials between religious groups. In both samples the point estimate of the return to schooling for Jews is lower than that of Protestants. Moreover in the Montreal sample it is Catholics who have the highest returns to schooling (row 15). In the Quebec sample only two significant differences emerge. First, the returns to Jews from a degree are significantly lower than to either Protestants or Catholics. Second, the estimated returns to schooling for Protestants are higher than to Catholics or the residual group. For the Montreal sample none of the differences in the human capital variables are statistically significant. Thus, while Jews in Canada typically receive greater returns to human capital in Canada, there exist some socio-economic environments in which Jews appear to do no better than the rest of the population.

\section{SUMMARY AND CONCLUSIONS}

This paper has examined differences across religious groups in the rate of return to human capital. An empirical analysis of the earnings of males using the 1971 Canadian Census reveals substantial differences. We find that Jews not only make greater investments in schooling, but also receive a rate of return on schooling which exceeds that of other groups by a sizeable margin. Moreover, the steeper earnings-experience profile of Jews is also consistent with greater investments in human capital and/or a higher rate of return on such investments. Another striking difference between Jews and non-Jews is that the 'credential' effect of a university degree for Jews is zero, whereas for other groups the possession of a degree is associated with $30 \%$ higher earnings (holding years of schooling constant). Among non-Jews we find that the payoff 
to Protestants from schooling, experience and a degree exceed those to Catholics. These findings imply considerable differences across religious groups in lifetime earnings (human wealth), holding earnings-generating characteristics constant.

These results are consistent with the view that different religious affiliations reflect substantive differences in abilities, opportunities, goals, values or family culture. If religious affiliation merely represents a superficial trait it is improbable that an earnings differential as large as that between Jews and non-Jews could persist for very 1ong. This paper has not identified the channels through which religious association affects earnings and the payoffs to characteristics. Nevertheless the fact that it is the groups with the highest levels of schooling (Jews and Protestants) who receive the highest rates of returns suggests that differences in 'ability factors' (shifting the demand for schooling) are more important than 'opportunity factors' (shifts in the supply curve reflecting differential costs of funds to finance education) in explaining religious differences in earnings.

The empirical results reported here are relevant to a number of hypotheses recently propounded. First, the finding that Jews not only make greater investments in schooling, but also receive a higher rate of return represents evidence against the hypothesis of Brenner and Kiefer (1981). These authors argue that because of their past cultural history, Jews invest more in human verses non-human capital and thus receive a lower rate of return on human 
capital. The results of this paper and those of Chiswick (1982) are that Jews receive a higher rate of return on human capital. This is consistent with Becker's conjecture that Jews have higher ability which results in marked differences in their earnings, occupation, schooling, fertility and other dimensions of behavior.

We also found that compared to Jews and Protestants, Catholics make smaller investments in schooling and receive a lower rate of return. This finding is contrary to a hypothesis employed in recent analyses of CatholicProtestant fertility differentials [see, e.g., Carliner et al, 1980; Robinson and Tomes, 1982]. These authors argue that because Catholics face additional psychic costs associated with the use of "artificial" birth control techniques, the price of numbers of children is lower for members of this religious group. As a result of this price differential Catholics are predicted to choose larger families and, due to "quality-quantity" substitution, make less investments per child, receiving a higher rate of return on their investments. On the contrary, however, we find that Catholics receive a lower rate of return on human capital than most other groups.

Religion appears to be an important dimension of family culture influencing earnings and the rate of return to human capital. The estimated effects of religion reported in this paper are "gross effects" in the sense that important dimensions of family background [parental income, education, family size, etc.] have not been held constant. An important topic for further research is to investigate the extent to which the differences documented in this paper persist when other dimensions of family background are controlled. 
TABLE A: SAMPLE MEANS

„SAMPLE

AIT

QUEBEC TORONTO MONTREAL

JEW

RCATH

RPROT

OTHER/

NO REL

$\underline{\text { Variable }}$

\begin{tabular}{|c|c|c|c|c|c|c|c|c|}
\hline EARN (\$000's) & 7.824 & 7.351 & 9.993 & 8.183 & 14.011 & 7.246 & 8.297 & 7.704 \\
\hline EDUC & 9.656 & 8.975 & 10.949 & 9.585 & 12.329 & 9.055 & 10.075 & 10.245 \\
\hline$T$ & 25.972 & 26.041 & 24.586 & 25.513 & 24.869 & 25.838 & 26.604 & 24.175 \\
\hline FR (\%) & 15.20 & 47.20 & 0.19 & 27.02 & 0.27 & 32.62 & 0.64 & 1.46 \\
\hline BILFR (\%) & 15.33 & 39.49 & 1.11 & 49.86 & 0.53 & 33.03 & 0.31 & 2.17 \\
\hline BILENG (\%) & 6.94 & 7.59 & 8.27 & 12.42 & 34.49 & 8.49 & 4.64 & 6.58 \\
\hline DEGREE $(\%)$ & 8.24 & 7.76 & 13.32 & 9.32 & 27.81 & 6.75 & 8.51 & 11.43 \\
\hline SELF (\%) & 14.51 & 13.16 & 8.34 & 8.85 & 33.16 & 13.03 & 14.90 & 17.20 \\
\hline GOVT (\%) & 9.61 & 8.39 & 6.92 & 7.57 & 2.67 & 9.58 & 10.26 & 7.88 \\
\hline LNWEEKS & 3.767 & 3.747 & 3.833 & 3.79 & 3.829 & 3.746 & 3.793 & 3.748 \\
\hline QUEBEC (\%) & 31.10 & 100.0 & 0.0 & 100.0 & 40.91 & 61.30 & 5.18 & 6.23 \\
\hline TOWN (\%) & 20.84 & 20.63 & 0.0 & 0.0 & 2.41 & 21.77 & 21.26 & 17.23 \\
\hline RNF (\%) & 17.00 & 13.41 & 0.0 & 0.0 & 0.53 & 15.97 & 18.74 & 16.20 \\
\hline FARM $(\%)$ & 7.27 & 5.17 & 0.0 & 0.0 & 0.0 & 5.72 & 8.42 & 9.91 \\
\hline JEW (\%) & 1.11 & 1.46 & 4.83 & 3.01 & 100.0 & 0.0 & 0.0 & 0.0 \\
\hline RCATH (\%) & 45.28 & 89.24 & 20.62 & 82.22 & 0.0 & 100.0 & 0.0 & 0.0 \\
\hline RPROT (\%) & 42.67 & 7.11 & 60.97 & 11.25 & 0.0 & 0.0 & 100.0 & 0.0 \\
\hline $\mathrm{N}$ & 33,726 & 10,489 & 3,167 & 4,623 & 374 & 15,270 & 14,390 & 3,692 \\
\hline
\end{tabular}

NOTES: 1. The education variable EDUC was coded as follows: No school: 0; < Grade 5: 3; Grades 5-8: 6.5; Grades 9-10: 9.5; Grade 11: 11; Grade 12: 12; Grade 13: 13; University 1-2 yrs: $13 \cdot 5$; Univ. $3-4$ yrs, without degree: 15.5; Univ. 3-4 yrs., with degree: 15.5; Univ. 5+ yrs., without degree: 17.5; University 5+, with degree: 17.5. Note that this assumes university entrance at the completion of grade 12. The figures for individuals with university education were adjusted to reflect differences across provinces in university entrance requirements using census information on the location of individuals at the completion of high school. The coding of schooling employed here is similar to that utilized by Vaillancourt (1980) and differs somewhat from that of Gunders on (1979). 
* This paper has benefitted from helpf $u l$ comments by Barry Chiswick, Glenn MacDonald, Chris Robinson and the referees. The usual caveat applies. $I_{\text {For a detailed discussion of the predictions of this model see }}$ Tomes (1982).

2 Taubman (1975, p. 194) mentions this point. This argument has also been attributed to Reuben Kessel.

${ }^{3}$ Data on the incidence of religious intermarriage are relevant to this issue, since if children adopt the religion of one parent or the other, higher rates of religious intermarriage will reduce the correlation between the religion of children and parents. In marriages contracted in Canada in 1972, $87.5 \%$ of Jewish grooms married Jewish brides; the corresponding figures for Roman Catholics and Protestants were $77.7 \%$ and $70.3 \%$, respectively. However, only $40 \%$ of Protestants married within the same Protestant denomination [Veevers, 1977, p. 18]. The latter figure suggests that Protestant denominations are reasonably 'close substitutes' and that the intergenerational continuity of families within a particular Protestant denomination may be considerably lower than for the broader Protestant classification. The reported figures may be upward biased measures of the correlation in religious background of spouses to the extent that spouses adopt the same religious affiliation in contemplation of marriage. Information on ethnic identification from the Canadian National Mobility Survey indicates that $94.6 \%$ of Jewish males claimed that their ancestors were also Jewish. By way of comparison the corresponding figure for English ethnic identity is $66.3 \%$. If Jewish ethnic and religious identification are highly correlated, which seems plausible, the above figure suggests a high degree of intergenerational transmission of Jewish religious affiliation in Canada. 
${ }^{4}$ The results of Taubman (1975) are suggestive. Taubman concludes from a study of the NBER-TH sample that "one of the major determinants of earnings was religion" (p. 101). Holding constant education, ability, self-employment status and an extensive 1ist of personal attributes and dimensions of family background, Taubman found that Jews received $33-40 \%$ more and Protestants 3-9\% less than Catholics and others (p. 40). Moreover, the growth rate of earnings of Jews (over a 15 year period) exceeded that of Catholics by $21 \%$ and Protestants by $26 \%$ (pp. 130-133). This latter result suggests either greater investments or higher rates of return on human capital for Jews than non-Jews and for Catholics versus Protestants. It should be noted, however, that Taubman's sample of veterans had higher than average ability and schooling.

${ }^{5}$ Chiswick's sample is restricted to adult U.S. native-born white men of foreign-born parents (i.e., sons of immigrants) with positive earnings from employment or self-employment.

6 Because Jews represent a small percentage of the population, the contribution of the Jewish variable to the explained variance $\left(R^{2}\right)$ and the beta coefficient are small. However, the regression coefficient implies a sizeable Jewish/non-Jewish differential, equivalent to the effect of 6.7 additional years of schooling.

${ }^{7}$ Lastly we note that Lacroix and Vaillancourt (1980) found in their analysis of Quebec males in the 1973 Highly Qualified Manpower Survey that individuals of Jewish origin earned $11 \%$ more than al1 others, holding constant years of schooling, type of schooling, experience and weeks worked (p. 52). 
The exact criteria are: (i) native-born males age 25-64, inclusive; (ii) Caucasian; that is, ethnic origin not Chinese, Japanese, native Indian, "negro", or West Indian; (iii) with positive weeks worked in 1970; (iv) positive income from employment and self-employment; and (v) able to speak at least one of the official languages.

The age criterion was chosen to encompass the years of labour market attachment after most individuals have completed schooling and before retirement. This should minimize the possibility of sample selection bias arising from the requirement of positive earnings. In the age group 25-64 only $6.9 \%$ of males are excluded due to zero earnings. In contrast in the cohorts $15-24,34.9 \%$ and $64+, 65.3 \%$ of males report zero earnings, suggesting that sample selection is a potentially important problem for these cohorts.

${ }^{9}$ The semi-log specification of the earnings function has received empirical support against alternative functional forms in the work of Heckman and Polachek (1974) and Welland (1978). When the 1 og of weeks worked is held constant, variations in the dependent variable reflect differences in weekly earnings. Tomes (1982) reports regressions which use the 1 og of the computed wage [annual earnings divided by usual hours worked $x$ weeks worked in 1970] as the dependent variable, and omit weeks worked as an explanatory variable.

${ }^{10}$ Alternatively, the degree variable may capture differences in college 'quality' (resources per student) or the intensity of investment [e.g., hours per day and weeks per year allocated to education]. Simple models of human capital accumulation rule out this later possibility by identifying schooling with a 'corner solution' in which all discretionary time is allocated to human capital investment. 
${ }^{11}$ This definition of the public sector excludes individuals employed in teaching, health, etc. who would be included within a broader definition. Moreover, we are unable, in these data, to distinguish between Federal, provincial and local levels of government.

${ }^{12}$ The 1971 Canadian Census identifies Jews both by religion and ethnic origin. The two variables are not independent, however, since statistics Canada recoded all individuals reporting Jewish religion as having a Jewish ethnic background [Richmond and Kalback, 1980, p. 32]. In our sample 92.12\% of ethnic Jews are also religious Jews. In the regressions reported here we have excluded ethnic Jews who are not also religious Jews (32 cases). Tomes (1982) reports empirical results using the slightly larger sample of ethnic Jews.

${ }^{13}$ See Ryder (1955) for a discussion of the usefulness and problems with ethnic identification in Canadian Census. Ryder's finding of significant shifts between certain ethnic groups (e.g., German and Netherlands) suggests that it would not be useful to further disaggregate the ethnic variables.

${ }^{14}$ Significance tests of the hypotheses of unequal coefficients across equations can be computed using the formula $t=\left(\hat{\beta}_{i}-\hat{\beta}_{j}\right) /\left(\sigma_{i}^{2}+\sigma_{j}^{2}\right)^{1 / 2}$ where $\sigma_{i}^{2}$ is the variance in the coefficient $\hat{\beta}_{i}$. However, this requires the strong assumption that the residuals in the two equations are uncorrelated. An alternative procedure, which requires only that the error structure be the same in the two subsamples, is to pool subsamples while introducing interaction terms, and conduct the usual t-tests. The significance tests reported in the text using this second procedure are derived from pooled regressions which permit the important variables (intercept, EDUC, T, TSQR and DEGREE) to differ across religious groups. 
${ }^{15}$ In relative terms the Jewish/Non-Jewish differential reported here is substantially larger than the $20 \%$ differential reported by chiswick (1982) for the U.S. Similarly, the differences in the slopes of the experience profiles and intercepts are greater in this study. See Tomes (1982) for a more extensive study of Jewish/non-Jewish differences.

${ }^{16}$ When the schooling variable (EDUC) was disaggregated into three components: years of schooling up to high school (SCHHS); years of university without a degree (SCHCND); and university with a degree (SCHCD), the following results were obtained for various subsamples, excluding the DEGREE variable:

$\begin{array}{lccccc}\text { Sample: } & \text { TEWS } & \text { JEWS } & \text { NON-JEWS } & \text { RPROT } & \text { RCATH } \\ \text { SCHHS } & 0.051 & 0.053 & 0.041 & 0.044 & 0.038 \\ t & {[2.050]} & {[1.722]} & {[13.448]} & {[16.404]} & {[15.385]} \\ \text { SCHCND } & 0.078 & 0.300 & 0.038 & 0.045 & 0.043 \\ & {[1.197]} & {[3.254]} & {[5.954]} & {[4.431]} & {[4.673]} \\ \text { SCHCD } & 0.078 & 0.132 & 0.100 & 0.114 & 0.085 \\ & {[3.391]} & {[4.316]} & {[34.061]} & {[25.850]} & {[19.211]}\end{array}$

Although, in the sample of all Jews the return to college without a degree of the coefficients on SCHCND and SCHCD

is imprecisely estimated, the point estimates/are identical. Moreover, in the sample of Toronto Jews the estimated return to college without a degree is double that of college with a degree! In contrast for all non-Jews, Protestants and Catholics the returns to college graduation are more than double the returns to college without a degree.

${ }^{17}$ These differences are significant at the $5 \%$ level.

${ }^{18}$ It should be noted that for the Jewish sample the language categories FR and BILFR contain very few observations, hence the language coefficients for this group are sensitive to 'out1iers'.

${ }^{19}$ Figures from the independent CMA Census sample suggest that over $90 \%$ of Jews in Ontario and Quebec reside in Toronto and Montreal, respectively. 


\section{REFERENCES}

Becker, G. S. (1981). A Treatise on the Family [Cambridge, Mass.: Harvard University Press].

Becker, G. S. and Tomes, N. (1979). "An Equilibrium Theory of the Distribution of Income and Intergenerational Mobility," Journal of Political Economy, Vo1. 87, No. 6, pp. 1153-1189.

Becker, G. S. and Tomes, N (1976). "Child Endowments and the Quantity and Quality of Children," Journal of Political Economy, Vo1. 84, No. 4, Part II, pp. S143-s162.

Becker, G. S. and Lewis, H. G. (1974). "Interaction Between Quantity and Quality of Children," in Economics of the Family, T. W. Schultz (ed.) [Chicago: University of Chicago Press].

Brenner, R. and Kiefer, N. (1981). "The Economics of Diaspora: Discrimination and Occupational Structure," in Economic Development and Cultural Change, pp. 517-533.

Carliner, G. (1981). "Wage Differences by Language Group and the Market for Language Skills in Canada," Journal of Human Resources, Vol. 16, No. 3, pp. 384-399.

Carliner, G., Robinson, C., and Tomes, N. (1980). "Female Labour Supply and Fertility in Canada," Canadian Journal of Economics, Vol. 13, No. 1, pp. 46-64.

Chiswick, B. R. (1982). "Do American Jews Really Over-Invest in Human Capital?" mimeo.

Corcoran, M., Jencks, C. and Olneck, M. (1976). "The Effects of Family Background on Earnings," American Economic Review, Papers and Proceedings, Vol. 66, pp. 430-435. 
Edlefsen, L. E. (1981). "The Comparative Statics of Hedonic Price Functions and Other Nonlinear Constraints," Econometrica, Vo1. 49, No. 6, pp. 1501-1520.

Featherman, D. L. (1981). "The Socio-economic Achievement of white ReligioEthnic Subgroups: Social and Psychological Explanations," American Sociological Review, Vol. 36, pp. 207-222.

Gocke1, G. I. (1969). "Income and Religious Affiliation: A Regression Analysis," American Journal of Sociology, Vo1. 74, pp. 632-646.

Greeley, A. M. (1976). Ethnicity, Denomination and Inequality [Beverly Hills: Sage Publications].

Griliches, Z. (1979). "Sibling Models and Data in Economics: Beginnings of a Survey," Journal of Political Economy, Vo1. 87, No. 5, Part 2, pp. s37-S64.

Gunderson, M. (1979). "Earnings Differentials Between the Public and Private Sectors," Canadian Journal of Economics, Vo1. 12, No. 2, pp. 228-242. Heckman, J. J. and Polachek, S. (1974). "Empirical Evidence on the Functional Form of the Earnings-Schooling Relationship," JASA, Vo1. 69, pp. 350-354. Janssen, S. G. and Hauser, R. M. (1981). "Religion, Socialization and Fertility," Demography, Vo1. 18, No. 4, pp. 511-528.

Kuch, P. and Haesse1, W. (1979). An Analys is of Earnings in Canada [Ottawa: Statistics Canada].

Lacroix, R. and Vaillancourt (1980). Attributs linguistiques et disparités de revenu an sein de la main-d'oeuvre hautement qualifiée au Québec, Québec: Conseil de la langue francaise.

Mincer, J. (1974). Schooling, Experience and Earnings [New York: N.B.E.R.]. 01sen, L., White, H., and Shefrin, H. M. (1979). "Optimal Investment in Schooling When Incomes are Risky," Journal of Political Economy, Vol. 87, No. 3, pp. $522-539$. 
Richmond, A. H. and Kalback, W. E. (1980). Factors in the Adjustment of Immigrants and Their Descendants [Ottawa: Statistics Canada]. Robinson, C. and Tomes, N. (1982). "Family Labour Supply and Fertility: A Two Regime Mode1," Canadian Journal of Economics (forthcoming).

Roof, W. C. (1981). "Unresolved Issues in the Study of Religion and the National Elite," Social Forces, Vol. 59, No. 3 (March), pp. 831-836.

Ryder, N. B. (1955), "The Interpretation of Origin Statistics," Canadian Journa1 of Economics and Political Science 21 (November), pp. 466-479.

Sewe11, W. H. and Hauser, R. M. (1976). Education, Occupation and Earnings Achievement in Early Career [New York: Academic Press].

Taubman, P. (1975). Sources of Inequality in Earnings [Amsterdam: North-Holland Publishing Co.].

Tomes, N. (1982). "Religion and the Rate of Return on Human Capital: Evidence from Canada," mimeo (April).

Vaillancourt, F. (1980). Differences in Earnings by Language Groups in Quebec, 1970: An Economic Analysis, Quebec, Centre International de Recherche sur le Bilingualism.

Veevers, J. E. (1977). The Family in Canada [Ottawa: Ministry of Supply and Services].

Warren, B. L. (1970). The Relationship Between Religious Preference and Socioeconomic Achievements of American Men, Ph.D. Dissertation, University of Michigan, Ann Arbor.

Welland, J. D. (1978). "Cognitive Abilities, Schooling and Earnings," Review of Economics and Statistics, Vol. 60, pp. 622-627. 